\title{
THE UNDERGROUND SYSTEM OF JUSTICE IN THE HOME ARMY'S RZESZÓW SUB-REGION
}

The Home Army's Rzeszów Sub-Region comprising the area confined within three rivers: San, Vistula and Wisłoka, and the Slovakian border in the south was spun off from the Home Army's Kraków Region in April 1943. The four Eastern Inspectorates were incorporated into the newly created Sub-Region, namely: Rzeszów, Przemyśl, Jasło and Mielec, and in each of them were created on the basis of pre-war communes.

On the basis of the statutes approved by the Commander-in-Chief, the Military Special Courts (WSS) were started to be established in 1941 within the military division, and the Civil Special Courts (CSS) within the civil division were created a year later. The first sentences concerning the Rzeszów area were passed in that court as early as in 1941.

Actions involving the execution of death penalties continue to raise a host of emotions and controversies. special squads (the so-called hit squads) were appointed as execution bodies of WSS by relevant commands of ZWZ/AK to be used to carry out execution sentences. As regards execution sentences, CSS hit squads were established by the Government Delegation for Poland (Delegatura Rzadu na Kraj).

It is worth noting that in the period from January 1941 to June 1944, the Home Army soldiers carried out executions of the total of 5,733 officers of the German Police, Military Police, and the SS. Such campaigns against the occupiers did not require court sentences. Based on the estimated calculations made by historians, it seems that special courts in Kraków and Rzeszów pronounced about one hundred death sentences.

Keywords: history of Poland, the Polish Underground State, the Home Army, the Office of Public Security, Military, military underground system of justice

\section{THE BEGINNING OF THE POLISH CONSPIRACY DURING WORLD WAR II}

After the occupants seized Poland, it became necessary to urgently organise an underground system of justice (as part of the military and political structures of the underground movement being established) that would safeguard the Polish rule of law and prevent spontaneous and arbitrary administration of judgements pronounced on Polish citizens. "Ubi societas, ibi ius", or where there is society, there is justice and a system of the law. According to this principle, as early as on 27 September 1939 Służba Zwycięstwu Polsce (SZP), or the Service for Poland's Victory, was created. Its first commander was General Michał Karaszewicz-Tokarzewski (nom de guerre "Torwid"), who, assisted by Stanisław Święcicki, Deputy Dean of Warsaw's Bar Council ${ }^{2}$, started work on the

${ }^{1}$ attorney-at-law, doctoral student at University of Rzeszów, Poland

2 Stanisław Święcicki (1897-1942), attorney-at-law, the last pre-war Deputy Dean of Warsaw's Bar Council, participant of the defence of Warsaw, actively involved in the Union of Armed Struggle (ZWZ) and the Government Delegation for Poland (Polish: delegatura Rządu na Kraj), arrested by 
establishment of foundations for the system of justice in the occupied Poland. The origins of special courts' system are related to attorney-at-law Władysław Sieroszewski (1900-1996) and the last pre-war dean of Warsaw's Bar Chamber, attorney-at-law Leon Nowodworski (1889-1941) ${ }^{3}$. The latter quickly withdrew from the works, since he did not want to personally endorse the establishment of courts in which the accused of a crime carrying the death penalty would not be provided with effective defence.

Issues relating to the involvement of pre-war lawyers in the bodies of the underground system of justice have been very rarely discussed. One of the few papers on the subject was an article published in 1977 by the above-mentioned Władysław Sieroszewski ("Sabała", "Paweł") (pre-war sub-prosecutor of the Supreme Court, and, during the occupation, the Chairman of the Home Army's Military Special Court for the Warsaw Region, and a known attorney-at-law in the post-war Warsaw). That and other scanty papers were, however, primarily focused on the main cities, such as Warsaw and Kraków 5 .

The underground scales of justice in the Rzeszów region have not been subject of many publications thus far, and the issue has been rather mentioned as a side remark to the more general works by Prof. Grzegorz Ostasz ${ }^{6}$. An excellent monograph by Piotr Szopa, a historian from a younger generation, was published in $2016^{7}$, which, presently, contains the fullest description of operations of the underground system of justice in that region. In this relatively short paper I wish to recollect the profiles of those meritorious lawyers who committed themselves, during a difficult period of the occupation in the area of the Home Army's Rzeszów Sub-Region, to install an effectively operating underground system of justice. Nonetheless, it must be borne in mind that a list of lawyers operating in the underground system of justice in that area is not full, since related information had a top secret status. The majority of documents dating back to that period is still missing

the Gestapo on 11 May 1942, and killed in a mass execution of prisoners in the Pawiak Prison on 15/16 October 1942, after: L. Gondek, W imieniu Rzeczypospospolitej. Wymiar sprawiedliwości w Polsce w czasie II wojny światowej (In the Name of the Republic of Poland. System of Justice in Poland during World War II), Warsaw 2011, p. 41.

${ }^{3}$ W imieniu Polski Walczacej (In the Name of Fighting Poland), interview with Dr Bartłomiej Szyprowski, "Do rzeczy - Historia" 2014, issue no. 7, p. 12.

${ }^{4}$ W. Sieroszewski, Organizacja wymiaru sprawiedliwości $w$ Powstaniu Warszawskim $i$ udzial $w$ niej adwokatów (Organisation of the System of Justice in the Warsaw Uprising and Involvement of Attorneys-at-Law), "Palestra" 1977, issue No. 7, but in the paper the author focused mainly on describing bodies of the system of justice in Warsaw, with special consideration given to the period of the Warsaw Uprising.

${ }^{5}$ L. Gondek, op. cit., passim with voluminous quotes from the work by W. Sieroszewski, Przyczynek do historii Wojskowych Sadów Specjalnych (A Contribution to the History of Military Special Courts), Warsaw 1974, msp, Archiwum Wojskowego Instytutu Historycznego (AWIH, or Archives of the Institute of Military History), III/50/66.

${ }^{6}$ G. Ostasz, Okręg Rzeszowski Zrzeszenia „,Wolność i Niezawisłość” (The Rzeszów District of the Freedom and Independence Association), Rzeszów 2006.

${ }^{7}$ P. Szopa, W imieniu Rzeczypospolitej. Wymiar sprawiedliwości Polskiego Państwa Podziemnego na terenie Podokręgu AK Rzeszów (On behalf of the Republic of Poland. System of Justice of the Polish Underground State in the Territory of the Home Army's Rzeszów Sub-Region), Rzeszów 2014, passim, see also: J. Forystek, Adwokaci w podziemnym wymiarze sprawiedliwości Podokregu AK Rzeszów (Attorneys -at-law in the underground system of Justice in the Home Army’s Rzeszow Sub-Region), "Palestra" 2016, issue no. 13, pp. 402-423. 
(part being seized by NKVD (People's Commissariat for Internal Affairs)). Lawyers, adjudicating in special courts, later worked in the bodies of the system of justice in postwar Poland and, being afraid of arrest, they hid their underground movement involvement. In those few documents that have been preserved, members of the adjudicating bodies and prosecutors would use quite frequently changed noms de guerre.

One of the main regions of the Union for Armed Struggle (ZWZ)/ Home Army (AK) was the Kraków Region (under the codenames of "Muzeum" (Museum), "Godło" (Coat of Arms)) that was divided into eight inspectorates (four Eastern ones: Rzeszów, Jasło, Przemyśl and Mielec, and four Western ones: Tarnów, Nowy Sącz, Kraków and Miechów). The inspectorates were further divided into districts, and those into outposts, where the basic units of the Home Army, or platoons, special operation units and squads, were operating.

\section{TERRITORIAL STRUCTURE OF THE HOME ARMY'S RZESZÓW SUB-REGION}

Until World War II, Rzeszów had been in the Lviv Voivodeship, but the courts had been subject to appeals made in Kraków. Located half way between Kraków and Lviv, it was influenced by those two university centres. Nonetheless, it was Kraków that exerted greater influence on the operations of the system of justice. After the defeat in September 1939, as a result of the Molotov-Ribbentrop Pact, the San River became a border between the Soviet and German occupation zones, and Rzeszów became a natural "capital" of German occupation territory of the former Lviv Voivodeship and, thus, a major centre of the military resistance movement. The Home Army's Rzeszów Sub-Region (codename "Ogniwo" (Link), "Woda" (Water), "Rezeda" (Reseda), "Wschód" (East)) comprising the area confined within three rivers: San, Vistula and Wisłoka, and the Slovakian border in the south was spun off from the Home Army's Kraków Region in April 1943, which was caused by the necessity of improving command and effectively prepare the would-be general uprising. The change coincided with the time when the Germans brough the Katyn massacre to light $^{8}$. The four Eastern Inspectorates were incorporated into the newly created Sub-Region, namely: Rzeszów ("Rzemiosło" (Craft), "Rtęć" (Mercury)), Przemyśl ("Paweł", "Płotka" (Small Fry), "Park"), Jasło ("Jemioła" (Mistletoe), "Joachim") and Mielec ("Nowela" (Novella), "Wrzesień" (September)), and in each of them a total of 15 districts were created on the basis of pre-war communes.

The Home Army's Rzeszów Sub-Region was headed by Col. Kazimierz Putek ("Zworny"), and, after his arrest by NKVD and the disbandment of the Home Army in February 1945, Maj. Stanisław Pieńkowski ("Hubert") became the commander of the Sub-Region "in liquidation". Since the date of the first arrest of "Zworny" by counterintelligence of the $1^{\text {st }}$ Ukrainian Front (12 December 1944), the operations of the Home Army in the entire Rzeszów area were actually headed by Maj. Łukasz Ciepliński

\footnotetext{
${ }^{8}$ On 11 April 1943 the "Transocean" Agency transmitted a message that the bodies of 10,000 Polish officers had been found in the Katyń Forest, and on 13 April 1943 the information was repeated by Radio Berlin. On 17 April 1943 "Ilustrowany Kurier Polski" (one of the rag dailies published in the occupied Poland) reported on the discovery of mass graves in the article titled Polish Officers being Victims of Bolshevik Atrocities together with the information that two generals had been identified - Bohaterewicz and Smorawiński.
} 
("Pług" (Plough)), who, following the arrests of members of the staff made in February 1945, started to recreate the structures of the commanding staff by appointing new commanders of the inspectorates ${ }^{9}$.

As from April 1941, Maj. Łukasz Ciepliński ("Pług” (Plough), “Antek”, “Apk”) was the commander of the Home Army's Rzeszów Inspectorate until Gen. Okulicki ordered the disbandment of the Home Army ${ }^{10}$. In February 1945, his associate, Maj. Adam Lazarowicz ("Klamra" (Buckle)), who had previously held the position of commander of the Home Army's Dębica District (codenamed "Deser" (Dessert)), was appointed a "liquidator." Jan Geron "11 ("Olek", "Wacław"), who acted as an aide and head of the staff chancellery, first of the District, and then of the Inspectorate ${ }^{12}$, was the closest associate of "Pług" (Plough) since the beginning of the underground movement in the Rzeszów area. That lawyer also became the first commander of the Home Army's Outpost "Świerk" (Spruce) (Świlcza-Trzciana) created by him.

\section{KANGAROO COURTS OF ZWZ (UNION OF ARMED STRUGGLE)}

Initially, the entire underground system of courts was reporting to the Main Headquarters of the Union of Armed Struggle. On 16 April 1940, the Country Committee of the Government of the Republic of Poland in France took a resolution on the establishment of court structures across Poland, and in May the "Kodeks sąów

${ }^{9}$ G. Ostasz, Podziemna Armia. Podokręg AK Rzeszów (Underground Army. The Home Army's Rzeszów Sub-Region), Rzeszów 2010, p. 276.

10 The first commander of the Home Army's Rzeszów Inspectorate was Maj. Władysław Bartosik ("Broda" (Beard)), who held the position from the end of 1939 until his arrest by the Gestapo on 26 April 1940.

11 Jan Geroń, ("Olek", "Wiesław”), born 11 August 1908 in Rzeszów - died 11 September 1979 in Jasło, since 1937 head of the Mortgage Department of the Borough Court in Rzeszów; involved in the underground movement since September 1939, one of the founders of the resistance movement in the Rzeszów area, he created underground structures based on his connections mainly within the legal milieu of Rzeszów, founder and first commander (since 1939) of the Home Army's Outpost "Świerk" (Spruce) (Świlcza-Trzciana) which produced many subsequent members of special courts and members of commanding staff of the Home Army in the Rzeszów area, one of the first persons to have been sworn in by Geron in the Union of Armed Struggle in December 1939 were: (i) Cadet Master Corporal Józef Koryl ("Piła" (Saw)), other possible nom de guerre: "507"), born 1913, pre-war non-commanding officer of the State Police, deputy commander of the Home Army's Outpost "Świerk" (Spruce) and non-commanding officer of intelligence and counterintelligence of the Home Army who was carrying out operational invigilation of the Gestapo's informers, (ii) Józef Kokoszka ("506"), born 1914, graduate of the Law [Faculty] at Jan Kazimierz University (UJK) in Lviv in 1937, pre-war judge, later chairman of the Branch Division of the Military Special Court (WSS) at "Rzemiośło" (Craft), (iii) Józef Frankiewicz ("Marcin”, "Wapień" (Limestone), "Korzeń" (Root)), born 1914, trainee notary in the offices of Dr Adam Mazurek, later prosecutor in the inspectorate's Branch Division of the Military Special Court (WSS) in which Józef Kokoszka was the chairman. In 1945, owing to the assistance of Władysław Pałka and Józef Kokoszka, he took up residence in Rybnik, in 1946 he was arrested by UB (Department of Security), communist secret police, and placed in the Montelupich prison in Kraków, where he underwent atrocious interrogations conducted, among others, by Józef Światło, he was released in 1948, and later worked in the District Court in Sanok.

12 G. Ostasz, A. Zagórski, Akcja "Burza" w Inspektoracie AK Rzeszów (Operation Tempest in the Home Army's Rzeszów Inspectorate), Kraków 2003, p. 508. 
kapturowych"13 (Code of Kangaroo Courts) was adopted. It provided for five types of crimes carrying the death penalty (treason, espionage, provocation, denunciation, and harms inflicted on Polish population), and it also created the rules of procedures before courts and appointment of adjudicating panels. The April resolution provided for the establishment of two divisions of criminal jurisdiction: the military division (for judging ZWZ members) and the civil division (for the citizens of the Republic of Poland who were not ZWZ soldiers). It was also ruled that until a civil special court was established within a given territory, as appointed by the Government Delegation for Poland, a special military court was competent to examine any cases, including those concerning civilians.

The kangaroo courts (SK) were to be composed of three judges of which at least one (most frequently the chairman) should meet the requirements of a military judge, but it was allowed to replace such judge by other pre-war lawyers (judges, attorneys-at-law, notaries public, prosecutors, and trainees). The other two members of the adjudicating panel, who did not necessarily have to have legal background, were appointed by the chairman of the Court acting on behalf of the relevant commanders of ZWZ/ AK. Additionally, the composition of the kangaroo court included: a prosecutor, an examining judge and a public defender for each of the accused. The list of rulings passed by the kangaroo courts was extremely short. They could adjudicate either a death penalty or acquittal.

\section{WSS'S (MILITARY SPECIAL COURTS) AND CSS'S (CIVIL SPECIAL COURTS)}

The kangaroo courts operated until November 1941 when, following the analysis of their operations thus far and common criticism of their name, "Statut Wojskowych Sadów Specjalnych" (Statute of Special Military Courts), drafted in Poland, was sent to the Polish Government in exile in London. On the basis of the statutes approved by the Commanderin-Chief, the Military Special Courts (WSS) were started to be established within the military division, and the Civil Special Courts (CSS) within the civil division were created a year later. The statutes of both types of courts were very similar, although the military division reported to the Main Headquarters of ZWZ/ AK and to individual commanders of sub-regions and areas of AK, while the civil division was subjected to the delegate of the Government Delegation for Poland. Thus, there was no competence disputes beetween courts, since their competences and responsibilities were explicitly separated. A CSS could not pass judgements on ZWZ/ AK soldiers, and a WSS could not do so on civil persons. The first CSS courts were established towards the end of 1942. They were to operate at the sub-region level of Government Delegations, but, from July 1943, such courts started to be created in individual inspectorates, too. After the Statutes of WSS and $\mathrm{CSS}^{14}$ were formally introduced in September 1942, a major simplification of the

13 "Kodeks Sadów Kapturowych" (Code of Kangaroo Courts), and "Statut Wojskowych Sadów Specjalnych" (Statute of the Military Special Courts) were issued in the form of an order of the chief commander of ZWZ, and not in the form of an act of law or a decree. In May 1940 the "Code of Kangaroo Courts" was executed by "Józef Goziemba" as the chief commander of ZWZ (it was the nom de guerre of Gen. Kazimierz Sosnkowski), and was approved by the Commander-in-Chief "Eugeniusz Strażica” (actually Gen. Władysław Sikorski).

${ }^{14}$ Following its approval by the Commander-in-Chief, Gen. Władysław Sikorski, the Statute of the Military Special Courts was sent to the Home Army commander on 3 September 1942. 
procedure followed, and it was adjusted to the occupational circumstances. The prosecutor was excluded from the court composition and the position of the examining judge was also eliminated. The procedure was divided into two parts: investigation (in the course of which evidence was collected) and the hearing. It was the prosecutor (accuser), as a body of the system of justice separate from the court, that instituted investigation on the basis of its own information, most frequently obtained from counterintelligence or reported by commanders. Until the appointment of the prosecutor, indictments were directly prepared by counterintelligence. In the course of investigation, the prosecutor co-operated with counterintelligence units of ZWZ/ AK that would collect incriminating evidence for them. Unlike kangaroo courts, WSS's and CCS's had much broader capabilities of administering various penalties: (infamy, whipping, admonition). The Statutes additionally introduced the possibility of having a case re-examined, staying of the penalty or the criminal proceedings themselves, if the penalty involved depravation of freedom only. Also, after a death sentence was pronounced, it became possible to stay its administration until the war was over. The convicted offender could rehabilitate themselves during that period ${ }^{15}$. "Non-approval of the sentence" by a relevant AK commander (with regard to WSS) and a delegate of the Government Delegation for Poland (with regard to CSS) was a crucial institution provided for in the Statutes, being a substitute of the "appeals." The Chairman of the Court would send the sentence or acquittal, together with the case files, for approval and, in case of conviction, also for execution. None of the Statutes provided, however, for a formal institution of appeals. A sentence pronounced by WSS was approved by a military commander at a relevant level. Following approval, it became final and was subject to execution. In case of refusal (such instances occurred many times, e.g. in the notorious case of Tadeusz Towarnicki ("De Vrana"), deputy commander of the 993/W squad $^{16}$, or the case concerning Podlaskie Bishop ordinary Czesław Sokołowski ${ }^{17}$ ), the case was transferred for re-examination by another adjudicating panel. The second sentence was immediately executable and was not subject to approval again. That institution was a kind of safety valve protecting against any miscarriage of justice by judges. Some of the sentences, mostly those pronounced by CSS's after 1942, were publicly announced in the underground press. Sentences by WSS's concerning AK soldiers were not publicly disclosed for security reasons.

Pursuant to the Statute of WSS, the chairman of the court was appointed by a relevant commander. The mode of proceedings whose goal was to find out the objective truth depended solely on the court's discretion. The sentence was passed by an absolute majority of votes cast, and the sentence of death penalty had to be unanimous. The positions of recommended prosecutors were usually taken by counterintelligence officers, most often pre-war lawyers, e.g. Lucjan Milewski ("Baczyński”) became a prosecutor at

${ }^{15}$ By way of example, that institution was used by WSS presided over by Maj. Maciej Kalankiewicz ("Kotwicz") in the case of cavalry Capt Józef Świda ("Lech") from the Niemen River Grouping of the Home Army who was convicted for accepting weapons from the Germans needed for fighting the Soviet troops.

${ }^{16}$ L. Gondek, op. cit., pp. 106-107, the Sub-Region Commander refused to approve the sentence of WSS for the Warsaw Area for the assault on a German shop of Meinl in Warsaw that had not been agreed with the superiors, and the same WSS reexamining it, stayed the case, and the heroic Cadet "De Vrana" was killed in the first days of the Warsaw Uprising.

${ }^{17}$ Ibidem, pp. 106-107 
the Main Headquarters of ZWZ, and attorney-at-law Henryk Rajzman ("Kornel”) was a prosecutor at the Regional WSS (codename "Waga" (Scales), "19000") in the Home Army's Silesia Region (codename "Kilof" (Pickaxe), "Węgiel" (Coal)). Likewise, positions of chairmen of special courts were held by pre-war lawyers. In Warsaw they included the already mentioned Władysław Sieroszewski ("Sabała"), Dr Konrad Zieliński ("Karol"), pre-war Chairman of the Court of Appeals in Lviv, Antoni Olbromski ("Krauze"), a judge of the Court of Appeals in Warsaw ${ }^{18}$, and attorney-at-law Wiktor Danielewicz ("Grunt" (Land)). According to "Sabała," special courts were composed of more or less an equal number of representatives of judiciary and the bar, and among attorneys-at-law a major part was accounted for by former judges and prosecutors who were transferred to the bar.

\section{CO-OPERATION OF THE PROSECUTOR AND SPECIAL COURTS WITH COUNTERINTELLIGENCE AND INTELLIGENCE OF THE HOME ARMY}

As already mentioned, until the appointment of a prosecutor, actions relating to preparation of indictment were performed by counterintelligence. It was counterintelligence that usually collected incriminating evidence, most frequently from reports by persons operating within counterintelligence and military intelligence. By way of example, Sub-Regional CSS in Rzeszów closely co-operated with Józef Baran ("Motor" (Engine)), district head of intelligence and information of the People's Security Guard (LSB). Following the appointment of a prosecutor, it was ZWZ/ AK intelligence officers who collected evidence, and the prosecutor would decide whether to discontinue or stay the case, or to file an indictment act. A pre-war policeman, Józef Koryl ("Piła" $(\mathrm{Saw}))^{19}$, was one of such intelligence officers in the area of the Home Army's "Rzemiosło" (Craft) Rzeszów Inspectorate. For example, operational invigilation and provision of evidence in the case of Józef Bugajski (born 1912), a prison guard "at the Lubomirski Castle" in Rzeszów, and another Gestapo informer, Franciszek Miś, who were liquidated on 26 May 1944 in Przybyszówka as part of Operation "Kośba" (Reaping) ${ }^{20}$,

${ }^{18}$ Ibidem, pp. 53-55. After the war, Antoni Olbromski ("Krauze") was the first Chairman of the Court of Appeals in Wrocław, quoted after: W. Sieroszewski, op.cit, p. 70.

19 Józef Koryl ("Piła" (Saw)), other possible nom de guerre: "507”), son of Jan and Aniela, née Rączy, born 13 March 1912 in Przybyszówka near Rzeszów, shot by unknown delinquents on Holy Saturday on 31 March 1945, aged 33, for a detailed bio note see J. Forystek, Koryl Józef, "Piła" [in:] MSBUDN (Małopolski Słownik Biograficzny Uczestników Działań Niepodległościowych, (Małopolska Biographic Dictionary of Independence Movement Participants)), vol. 17, Kraków 2015, pp. 82-83.

${ }^{20}$ Operation "Kośba" (Reaping) carried out in a period from May 1944 to the end of the German occupation involved the liquidation of dangerous agents and collaborators as part of preparations for Operation "Burza" (Tempest). In the Home Army's Rzeszów District, 100 informers and traitors were liquidated, also including Polish-speaking Hans Flaschke and Friedrich Pottenbaum, heads of the Gestapo in Rzeszów, who were killed on 25 May 1944. The Home Army carried out similar operations in 1943: Operation "C" (Cleaning) conducted on 20-25 May 1943 and Operation "Wrzód" (Ulcer) carried out from 7 September 1943 that was anti-banditry in nature and Operation "Główka" (Little Head) continued from winter 1943, during which Włodzimierz Halicki, head of kripo, or the criminal police, in Kolbuszowa, was killed on 15 March 1944 in the town's market square. 
was carried out by an outpost of the Home Army's intelligence unit. Soldiers of the intelligence and subversion squad codenamed "Ruch" (Movement), organised and headed by the legendary Capt Józef Lutak ("Dyzma", "Roch"), established in the first half of 1943 the names of 41 persons collaborating with the Gestapo. At least thirteen persons were either liquidated or attempts were made to liquidate them.

Created on 7 February 1944 investigative expertise units (PES) were auxiliary bodies of special courts whose tasks included searching for (through intelligence brigades) and fighting any symptoms of common crimes (banditry, robbery, plunders, extortion payments for non-existing independence organisations, and blackmailing). Their tasks that were actually carried out since mid-1944 included covering the area with a network of intelligence, conducting investigations aimed at identifying perpetrators of crimes, sending results of investigations to special courts and carrying out sentences passed by special courts. It is worth noting that Germans did not succeed in discovering any of the expertise units ${ }^{21}$. Another auxiliary body was the National Security Corps (Państwowy Korpus Bezpieczeństwa (PKB)), an underground force being the core of the future state police, that was mainly composed of pre-war policemen and members of the People's Security Guards (Ludowe Straże Bezpieczeństwa (LSB)) operating in rural areas. PKB reported to the Government Delegation for Poland.

\section{REGIONAL WSS CODENAMED "WAGA" (SCALES) IN KRAKÓW}

Before a Branch Division of the Military Special Court (WSS) had been created in the Home Army's Rzeszów Sub-Region, cases concerning criminal offences committed in that area were examined by WSS in Kraków (codenamed "Waga" (Scales), "201," "0/1," or "7/1"). The Kraków court was then probably headed by Capt. Józef Jachna ("Waga" (Scales)), hence the court's name, while an unidentified person using nom de guerre "Długi" (Long) was its prosecutor. Judges were persons with noms de guerre "Lewart" and "Ton" (Tone) ${ }^{22}$, whose actual names have remained unidentified until today. The first sentences concerning the Rzeszów area were passed in that court as early as in 1941. As P. Szopa established in his publication, during the arrest of Home Army inspector from Jasło, Maj. Witold Obidowicz ("Wit", "Wiktor") in February 1942, three sentences were discovered on him carrying the death penalty for collaboration with the Gestapo.

There were many cases reviewed by the court, since as early as on 14 October 1943 the then commander of the Region, Col. Józef Spychalski ("Luty" (February)), issued an order to improve criminal proceedings pending at that time by means of filing criminal information according to a strictly defined form, including also references to witnesses by their noms de guerre (if they were members of the underground movement) or a code (if they were persons not involved in the underground activities). In the order he indicated the need to have testimonies made by witnesses by their own hand. At the same time, he also noted that "arbitrary and unjustified execution of the death penalty shall be

\footnotetext{
${ }^{21}$ T. Seweryn, Polskie sądownictwo podziemne (Polish Underground Courts), "Przegląd Lekarski" 1966, issue no. 1, pp. 216-217.

${ }^{22}$ As yet, there has been no detailed information about the composition of WSS "Waga" (codenamed Scales). The above information quoted after: P. Szopa, op. cit., p. 95.
} 
punishable",23. Commanders at lower levels formulated their orders in a similar manner. By way of example, the commander of the Home Army's Łańcut District, Capt Ernest Wodecki ("Szpak" (Starling)), in his order No. 4/43 of 22 October 1943, issued a few days later, wrote: "I once again prohibit arbitrary execution of sentences on Poles and Ukrainians. The death penalty sentences may be carried out only after the same have been approved by WSS (Military Special Court)"24. That prohibition was reinstated yet again in another order No. 5/43 of 17 November $1943 .{ }^{25}$ Those orders seem to confirm an argument that instances of mob law occurred in the Kraków Region, since commanders at various levels had to act as decisively as they did. Every quarter, WSS "Waga" (codenamed Scales) would send reports from its operations to the Home Army's Main Headquarters $(\mathrm{KG} \mathrm{AK})^{26}$. P. Szopa described four cases of persons from the Rzeszów area that were brought onto a docket of WSS "Waga"27 (codenamed Scales), namely: (1) forester Józef Lupa, resident of Łopuszki near Przeworsk, sentenced to death penalty for collaboration with the German military police in tracing Home Army soldiers who on 2/3 March 1942 participated in an operation carried out at the weaponry warehouse in Nienadowa - the sentence was executed on 5 October 1942, (2) Mikołaj Sawicki, a teacher in Pawłokoma near Krosno, a Ukrainian nationalist, sentenced for numerous cases of denouncing the inhabitants of Pawłokoma. The death penalty was executed on 14 October 1942, (3) Stanisław Morawiecki, a Gestapo informer and milk inspector in Rokietnica, who was liquidated in the brick factory in Czelatyce in December 1942, (4) Władysław Kmiecik, a pre-war restaurant operator from Jasło, sentenced for collaboration with the Gestapo, who was executed on 9 January 1943. There were many more such cases, and some of them have been discussed in more detail in the work of P. Szopa.

\section{REGIONAL CIVIL SPECIAL COURT (CSS) IN KRAKÓW}

Kraków's CSS was created at the beginning of 1943, and, most certainly, it was operational already in April 1943. In the quoted work of P. Szopa it is stated that on 27 April 1943 and 2 May 1943 the sentences of CSS passed on Michał Klimończuk (officer of Tramwaje Miejskie (Municipal Trams)) and Karol Bielecki (officer of the so-called Navy-Blue Police) were carried out in Kraków. Rudolf Günter ("Ciupaga" (Shepherd's Axe), "Sylwer", "Rudolf Sylwer") [1886-1979] became the Chairman of the Regional CSS, followed by attorney-at-law Jerzy Nasierowski ("Jaszczur" (Lizard), "Tur" (Aurochs)). The members of that CSS also included: Władysław Wójcik ("Czerski”, "Żegota") and Tadeusz Zygmunt ("Chmiel” (Hop), "Radło" (Ard)).

\footnotetext{
${ }^{23}$ Archiwum Państwowe w Rzeszowie (APR) (State Archives in Rzeszów), 108/113. Oryginalne dokumenty AK o treści organizacyjnej (Original Home Army Documents on Organisation), Order, 14 October 1943, sheet 276.

${ }^{24}$ Ibidem, Order no. 4/43, 22 October 1943, sheets. 219-220.

${ }^{25}$ IPN Rz 105/20 (Institute of National Remembrance in Rzeszów), Archiwum KW PZPR $w$ Rzeszowie (Archives of the Voivodeship Committee of the Polish United Workers' Party in Rzeszów), Order no. 5/43 of the Command of the "Losoś" (Salmon) District, 17 November 1943, sheets 6-8.

${ }^{26}$ Those interested in a detailed description of how the underground system of justice operated in the Region of Kraków should refer to the work by Tadeusz Seweryn, cf. T. Seweryn, op. cit., pp. 1-18.

27 P. Szopa, op. cit., pp. 102-105.
} 
The prosecutor in that court was Tadeusz Seweryn ("Socha" (Sokha)), "Białowąs", "Maszyński") [1894-1975], and Jan Kowalkowski ("Halszka") became the commander of the executive section. According to T. Seweryn, the entire court archives of that CSS were seized in June 1945 by the Soviet authorities ${ }^{28}$, however, according to his findings, during its operations until October 1944 Kraków's CSS pronounced 67 death penalties ${ }^{29}$. In October 1943 (a few months after its creation) Seweryn drafted "Zasady ogólne postępowania przed CSS" (General Rules of Procedure in Civil Special Courts), where it was indicated that, due to the fact that in each case referred to CSS pronouncement of the death penalty had to be considered, "it was not allowed to omit the circumstances in favour of the accused", since "the system of underground justice passing sentences in the Name of the Republic of Poland, despite operating in the underground system, had to safeguard the dignity of the Polish Nation." 30

\section{BRANCH DIVISION OF THE MILITARY SPECIAL COURT (WSS) CODENAMED "WAŻKA" (DRAGONFLY) IN RZESZÓW - IN THE HOME ARMY'S RZESZÓW SUB-REGION}

The Branch Division of WSS in Rzeszów (codenamed "Ważka" (Dragonfly)) was created in the Home Army's Rzeszów Sub-Region in the first half of 1943. A known notary public from Rzeszów, Dr Adam Mazurek ("Wojbor"), became its chairman" ${ }^{31}$. The court was composed of the following persons: Władysław Garnowski ("Lech"), later chairman of the Communist Military Supreme Court, responsible for many sentences pronounced on Home Army soldiers, Tadeusz Migdał, judge of the Supreme Court Branch Division in Kraków, Bolesław [Józef] Szymański, prosecutor of the Court of Appeals in Kraków, unidentified person, Master of Laws, the then bailiff of the Borough Court in Rzeszów, and Dr Józef Jedliczka ("Rydlewski”) as prosecutor (accuser) ${ }^{32}$. The composition of that court was presented somewhat differently by its Chairman Dr Adam Mazurek. According to him, the composition of the court included Mieczysław

${ }^{28}$ IPN Kr 07/135 (Institute of National Remembrance in Kraków), vol. 2, Akta śledcze przeciwko Tadeuszowi Sewerynowi (Investigative files against Tadeusz Seweryn), Report on the hearing of witness Tadeusz Seweryn of 14 December 1953, sheets 20-23.

${ }^{29}$ T. Seweryn, op. cit., p. 214.

${ }^{30}$ IPN Rz 105/5 (Insitute of National Remembrance in Rzeszów), Archiwum KW PZPR $w$ Rzeszowie (Archives of the Voivodeship Committee of the Polish United Workers' Party in Rzeszów), Zasady ogólne postępowania przed CSS (General Rules of Procedure Before the Civil Special Courts), 14 October 1943, sheet 26.

${ }^{31}$ Dr Adam Mazurek ("Wojbor", "s3", “42”), captain, notary public, run a notarial office in Rzeszów before the war and during occupation; in 1943 he became Chairman of the Branch Division of the Military Special Court codenamed "Ważka" (Dragonfly) in the Home Army's Rzeszów Sub-Region, in September 1944 he joined the Polish "People's" Army.

32 Dr Józef Jedliczka ("Rydlewski”), captain, pre-war district judge in Żmigród, since 1928 subprosecutor in the regional court in Rzeszów, during the occupation acted as a prosecutor (accuser) since 1943 in the Military Special Court codenamed "Ważka" (Dragonfly) established in the Home Army's Rzeszów Sub-Region, post-war prosecutor of the Regional Court in Rzeszów, and later Chairman of the Regional Court in Rzeszów; IPN Rz 037/8, Akta kontrolno-śledcze p-ko Władysławowi Piatkowi $i$ innym (Investigative and control files against Władysław Piątek and others), report on the hearing of witness Władysław Garnowski, 16 September 1949, sheets 127-128. 
Rachwał ${ }^{33}$, Tadeusz Migdał and Władysław Garnowski, and Dr Józef Jedliczka and Józef Szymański were the prosecutors. Grzegorz Ostasz, in turn, also mentions Adam Jagielski as a prosecutor of that court ${ }^{34}$.

At the time when the Red Army was approaching Rzeszów, the composition of "Ważka" (Dragonfly) was almost completely disassembled, since Władysław Garnowski left Rzeszów in mid-July and started to live in Iwonicz, and the Chairman himself, Capt Dr Adam Mazurek ("Wojbor"), joined the Polish "People's" Army in September 1944 having consent of his Home Army superiors. Further to that, on 3 November 1944 "Zworny," the Commander of the Rzeszów Sub-Region, in a document called "X1 to $\mathrm{R} 1, " 35$ stated that he was intending to appoint a new composition of WSS, taking into account judges from the "inspectorate's Military Special Court in R" first ${ }^{36}$, which confirms that the inspectorate's Military Special Court of "Rzemiośło" (Craft) chaired by Józef Kokoszka ("506") was already operational. In mid-November 1944, once the archives of the court were handed over by "Wojbor", WSS "Ważka" (Dragonfly) actually discontinued its operations. It is worth noting that Władysław Garnowski came back quickly to Rzeszów, since the report of the Home Army's counterintelligence for a period of 14 to 21 October 1944 on arrival of the court from "Lublin" read that: "Its composition included District Judge Garnowski of Rzeszów, known for severe sentences on Communists, and currently being an ultra loyal - It is a mil[itary] court."37 According to J. Borowiec, Garnowski became a very harsh judge serving the Communists ${ }^{38}$.

According to the estimates by P. Szopa, WSS "Ważka" (Dragonfly) passed some forty to fifty sentences. The author has found twenty persons on whom that court could have passed sentences, but there are no doubts only in one case, where the sentence was preserved in the form of a document.

\section{BRANCH DIVISION OF THE CIVIL SPECIAL COURT (CSS) CODENAMED "REJON" (REGION) IN RZESZÓW - IN THE HOME ARMY'S RZESZÓW SUB-REGION}

The codename of that Court is not known for certain, but in a letter of 16 June 1944 written by an accuser for the court, attorney-at-law Władysław Martynuska, ${ }^{39}$ to regional

33 G. Ostasz, Podziemna Armia ... (Underground Army), p. 88, p. 320.

${ }^{34}$ Ibidem, p. 320.

35 "X1" is a nom de guerre of Col. Kazimierz Putek, Commander of the Home Army's Rzeszów Sub-Region.

${ }^{36}$ APR, 108/116, Oryginalne dokumenty AK o treści organizacyjnej (Original Home Army Documents on Organisation), Report, 3 November 1944, sheet 141.

${ }^{37}$ IPN BU 944/46, Akta sadowe w sprawie p-ko Lukaszowi Cieplińskiemu i innym (Court files in the case against Łukasz Ciepliński and others), Counterintelligence report for 14 to 21 October 1944 , sheet 158 .

38 J. Borowiec, Aparat bezpieczeństwa a wojskowy wymiar sprawiedliwości. Rzeszowszczyzna 1944-1954 (Security Police and the Military System of Justice in the Region of Rzeszów 1944-1954), Warszawa 2004, p. 27, p. 166, p. 213.

39 Władysław Martynuska ("Zagroda" (Farmstead), "Ryś" (Lynx), "Nałęcz") vel Władysław Ulanowski (1912-1988), lieutenant, graduate of the Faculty of Law of Jagiellonian University (UJ), attorney-at-law, peasant movement political activist, delegate of the Government Delegation for Poland in exile for the district of Rzeszów; detailed bio note in: G. Ostasz, Martynuska Władysław, Małopolski Stownik Biograficzny Uczestników Działań Niepodległo- 
prosecutor T. Seweryn "Socha" (Sokha) requesting approval of the sentence of the Branch Division of CSS (and, usually, all sentences of that branch division were additionally approved by the Region), it appears that the court could use the codename "Rejon" (Region) and that is the name that P. Szopa favours. In autumn 1943, the first prosecutor in the Rzeszów CSS became attorney-at-law Władysław Martynuska, the then activist of SL "Roch" (Roch Peasants' Party) and a delegate of the Government Delegation for Poland for the district of Rzeszów, a pre-war attorney-at-law trainee in the offices of Dr Czarnek (who died in Auschwitz), and deputy of attorney-at-law Dr Stefan Hakala (who was murdered by NKVD in Kozielsk in spring 1940) during the occupation. At the same time, Martynuska was an organiser of that court, and he acted as an accuser at least until July 1944. Władysław Zimny ("Dunin"), proposed by the peasant movement, became the Chairman of CSS "Rejon" (Region), and the judges were: Jan Mirek ("Drzazga" (Splinter)) from PPS (Polish Socialist Party), and Jan Wiercioch, a peasant movement activist. "Dunin" (the then employee of the tax office) indicated "Drzazga" (Splinter) as the court chairman, who acted as deputy voivode from 18 November 1944 and as voivode of Rzeszów from 1947. These findings are further confirmed in a letter of the Voivodeship Office of Public Security (WUBP) in Rzeszów of 8 March $1951^{40}$ which reads: "During the occupation Martynuska was a prosecutor of the Civil Special Court and organised the composition of that court that included: mgr Władystaw Zimny as its chairman on behalf of the peasant movement, Jan Mirek, member of CSS representing the Polish Socialist Party (PPS), and Jan Wiercioch, court member representing the peasant movement, from whom Martynuska took an oath of allegiance to the Polish Government in exile (in Lonodon." The composition of CSS was also confirmed by Dr Andrzej Kuś (1884-1958), a peasant movement activist involved in the operations of the political department of the Government Delegation for Poland, in his testimony of 21 December 1950 made in the Voivodeship Office of Public Security (WUBP) ${ }^{41}$. Sessions of the court were held in the law office of Martynuska in Rzeszów at Grunwaldzka Street ${ }^{42}$.

The Rzeszów CSS ended its operations under the Soviet occupation in February 1945. The court was dealing with many cases ${ }^{43}$, the best known of which is the case of Mieczysław Piątek, a resident of Słocina, accused of complicity with other persons in murdering four Jews, on 22 November 1943 in Słocina, who were being led out of the ghetto in Rzeszów, under the guise of transferring them into Hungary. The case concerning acts performed by three of the perpetrators (who were Home Army soldiers), as not being subject to the jurisdiction of CSS, was excluded and transferred to WSS.

ściowych 1939-1956 (MSBUDN) (Małopolska Biographic Dictionary of Independence Movement Participants), vol. 4, Kraków 1999, pp. 123-125.

${ }^{40}$ IPN Rz 00 141/919/J, Akta operacyjne dot. Wtadystawa Martynuski (Operational Files on Władysław Martynuska), sheets 13-14.

${ }^{41}$ Ibidem, sheet 20, a bio note of Andrzej Kuś in: Malopolski Stownik Biograficzny Uczestników Działań Niepodległościowych 1939-1956 (MSBUDN) (Małopolska Biographic Dictionary of Independence Movement Participants 1939-1956 (MSBUDN)), Kraków 1997, vol. 2, pp. 79-81.

${ }^{42}$ IPN Rz 042/927, Akta operacyjne przeciwko Wtadystawowi Martynusce (Operational Files against Władysław Martynuska), Letter to the Head of the $5^{\text {th }}$ Division of the Voivodeship Office of Public Security (WUBP) in Opole, 8 March 1951, sheet 22.

${ }^{43}$ P. Szopa, op. cit, pp. 311-328. The author describes many cases run by that CSS, including, among others, the cases of: Andrzej Lewczuk, Franciszek Bełza, Stanisław Gut, Stefan Puka, Władysław Sitek, Michał Krupa, Maria Cz., and Wojciech Sudolski. 
According to Martynuska, WSS pronounced the death penalty on them. But, in the case of Mieczysław Piątek, CSS refused to pronounce a death penalty sentence and suspended the proceedings ${ }^{44}$, offering a chance for rehabilitation.

During the Soviet occupation, CSS would also examine the cases of Leopold Toman, Civic Militia (MO) officer, Adamczyk from the People's Army (AL), and Stanisław Marczak, a Communist activist and mayor of Błażowa. The CSS sentence against Stanisław Marczak was carried out on 7 February 1945 by an execution group headed by Stefan Sieńko ("Ikar" (Icarus), " $88 \mathrm{~S} " \mathrm{~S}^{45}$. According to Martynuska, the court passed four death penalties by the end of May 1944.

\section{MILITARY SPECIAL COURT (WSS) CODENAMED "RZEMIOSLO" (CRAFT) AT THE HOME ARMY'S RZESZÓW INSPECTORATE}

From the beginning of 1944, further to the preparations for Operation "Burza" (Tempest), the Branch Divisions of the Military Special Courts (WSS) started to be created. Orders requesting the creation of such branch divisions were appended with the forms of documents to be used, namely: an indictment act, a quarterly report, a judge oath, and a general instruction on operations of WSS.

As from the time when Rzeszów was seized by the Red Army (2 August 1944), the Home Army's Rzeszów Sub-Region was cut off by the front line from the Home Army's Kraków Region. Paradoxically, that circumstance expedited the establishment of underground court system in that area, both at the level of the Sub-Region itself and, primarily, of the Home Army's Rzeszów Inspectorate codenamed "Rzemiosło" (Craft). WSS for the Rzeszów Inspectorate most certainly started its operations under the Soviet occupation, just like other branch divisions of the Kraków Region operating from autumn 1944, for example in the inspectorate of Nowy Sącz, Miechów or Tarnów.

Józef Kokoszka ("506"), a pre-war judge of the Borough Court in Lviv and a close associate of Józef Frankiewicz, the commander of Outpost "Świerk" (Spruce), also a graduate from the Faculty of Law at Jan Kazimierz University (UJK) in Lviv, became the chairman of the Military Special Court (WSS) for the Inspectorate. It may be safely claimed that the court was primarily composed of persons coming from Trzciana or neighbouring towns. The judges from Trzciana were: Jan Draus ("Dym" (Smoke)) ${ }^{46}$, Zdzisław Pyziak and Bronisław Kawalec, brother of the later commander of the "Żbik" (Wildcat) ${ }^{47}$ District. Władysław Pałka, another judge and associate of Kokoszka from the

${ }^{44}$ IPN Rz 353/129, Akta w sprawie karnej przeciwko Wladysławowi Piatkowi i towarzyszom (Files in the criminal case against Władysław Piątek and his companions), according to those files under the sentence of the Court of Appeals in Rzeszów of 31 May 1950, Władysław Piątek and Mieczysław Piątek were sentenced for that act to the penalty of 10 years in prison. The court recognised that since "they are relatively young people, therefore, a possibility of their improvement may not be all together excluded and that is why sentencing them to death or life-time imprisonment would not be right."

${ }^{45}$ P. Szopa, op. cit., p. 323.

46 Jan Draus ("Dym" (Smoke)), son of Stanisław and Zofia née Łagowska, born 21 October 1919 in Trzciana, lawyer, courier, and liaison of the Home Army's Outpost "Świerk" (Spruce) for the Home Army's "Rozbratel" District.

${ }^{47}$ Mieczysław Kawalec (“Iza”, “Żbik” (Wildcat), “69”), son of Józef and Katarzyna, born 5 July 1916 in Trzciana, colonel, graduate and assistant to Prof. Władysław Grabski at the Faculty of 
Faculty of Law at Jan Kazimierz University (UJK), the later attorney-at-law of the chamber in Katowice, was from the nearby Mrowla. As argued by Mieczysław Wałęga ("Jur"), long-time head of military intelligence and military counterintelligence in the Rzeszów Inspectorate, it was quite unusual, since, as a rule, they tried not to combine functions in intelligence with the work in a special court. It must be remembered, however, that the court was created in extraordinary times, just after Rzeszów had been captured by an "ally of our allies" and following executions of Home Army soldiers by NKVD. The core of the Branch Division was thus formed by Home Army soldiers from the Outpost "Świerk" (Spruce) (Świlcza-Trzciana). The prosecutor was most probably Józef Frankiewicz ("Marcin", "Korzeń" (Root)), also from Trzciana. According to G. Ostasz ${ }^{48}$ the composition of that Court also included: second lieutenant Franciszek Czajak-Rudnicki ("Maczuga" (Mace)) from Przybyszówka, Józef Nyzio from Trzciana and Stanisław Osetkowski ("Zając" (Hare)). A Summary Adjudication Group was another operating unit in the Outpost "Świerk" (Spruce) in which the following persons from Trzciana were involved: Mieczysław Łagowski ("Iskra" (Spark)), intelligence officer, Bolesław Jastrzębski ("Jastrząb” (Hawk)), subversion officer, Jan Przybyło ("Marian”), Franciszek Litwin ("Marian”), Michał Frankiewicz ("Kaczor” (Duck)) and, occasionally, Tadeusz Dziedzic ("Grusza" (Pear Tree)). It has not been determined yet whether the members of the group were also judges of WSS for the Inspectorate. That Branch Division of WSS most probably pronounced sentences that were carried out at the end of 1944 and the beginning of 1945, that is already under the Soviet occupation. Probably, that WSS also pronounced the death penalty on Wojciech Kocan ("Mak" (Poppy)), "Czarny Sędzia" (Black Judge)), a corrupted Home Army soldier from Przybyszówka, which was subsequently approved personally by Adam Lazarowicz ("Klamra" (Buckle)), an inspector from Rzeszów. The death penalty sentence "in the name of the Republic of Poland..." was carried out on 8 April 1946 by the outpost execution group headed by Franciszek Czajak-Rudnicki ("Maczuga" (Mace)) and composed of: Bronisław Adamiec ("Rak" (Crayfish)), Bronisław Migała ("Mauser"), Jan Krupa, probably Kazimierz Ciebiera ("Wiktor"), and two other unknown persons 49 .

Law at Jan Kazimierz University in Lviv; Home Army intelligence officer, deputy commander, and from November 1944 to 5 February 1945 a commander of the Home Army's Rzeszów district; from 1945 actively involved in Freedom and Independence (WiN); sentenced to four death penalties in a show trial from 5 to 14 October 1950 of the so-called $4^{\text {th }}$ management board of WiN, killed with a shot in the back of the head on 1 March 1951. His symbolic grave is located at the Military Cemetery in Powązki in Warsaw in the "Na Lączce" (Meadow) Quarters. Detailed bio note in G. Ostasz, A. Zagórski, Akcja “Burza"... (Operation Tempest), pp. 544-545.

${ }^{48}$ P. Szopa, op. cit., pp. 211-213, G. Ostasz, Okręg Rzeszowski... (Rzeszów Region), p. 440, Likewise, M. Maruszak, Działalność żotnierzy AK z plutonu dywersyjnego "Zagłoby" (1944-1952) w dokumentach UB (Operations of Home Army Soldiers from the "Zagłoba" Subversion Platoon (1944-1952) in the UB Communist Secret Police Documents), Zeszyty Historyczne WiN-u, (ZH WiN) (Freedom and Independence Historical Studies) 2005, issue no. 23, p. 40.

${ }^{49}$ G. Ostasz, Okręg Rzeszowski ... (Rzeszów Region), p. 462, Wojciech Kocan ("Mak” ((Poppy)) was also accused of the death of his commander, Józef Koryl ("Piła" (Saw)). For detailed description of the execution of W. Kocan cf. M. Maruszak, Oddziat Franciszka Rejmana "Bicza" i Leona Stowika "Uzdy". Geneza, struktury i działalność (1944-1947) (Squad of Franciszek Rejman "Bicz" (Whip) and Leon Słowik "Uzda" (Headcollar). Origins, Structures and 
It seems that he continued the operations also after the formal disbandment of the Home Army, i.e. in a period when the structures of "Nie" (No), the Armed Forces Delegation for Poland operated and the Freedom and Independence (WiN) Association had its beginning, until 1946, when the majority of judges left the Rzeszów area due to the threatened breach of conspiracy and, under false identifications, set out for Silesia or the Regained Territories to hide from the [Communist] security service. Until today, no copy of any of the sentences pronounced by that Court have been found, and many executions carried out by informal groups of Stanisław Piela ("Kościarz") and Franciszek Rejman ("Bicz" (Whip)), and the band of Wojciech Kocan on the inhabitants of the surrounding towns and villages were attributed to that court by perpetrators in investigations conducted before the Communist law enforcement authorities.

\section{MISCARRIAGES OF JUSTICE}

No legal system is free from the so-called miscarriages of justice, hence a procedure of appeals is applied to verify them. Miscarriages occur event at times of peace and in courts in established democracies (such as USA, UK or Germany), also in cases whereby death penalties are pronounced. Thus, it is one of the key arguments of the death penalty opponents. As I have already mentioned at the beginning, it was because of that reason that attorney-at-law Leon Nowodworski refused to further participate in the works on the establishment of underground special courts before which the "right to defence" was illusory or virtually non-existent due to objective reasons. He rightly anticipated that the cases of miscarriages of justice would all the more so occur in special courts operating by default. Sentences passed by default would have to be based on information provided by Home Army intelligence and counterintelligence officers that was not fully verified. The issue of miscarriages of justice requires further in-depth historic research, and the topic will certainly raise numerous controversies event after the lapse of many decades. It seems that during the Nazi occupation the number of miscarriages of justice was relatively smaller, since the death penalties were passed rarely (e.g. CSS "Rejon" (Region) in Rzeszów pronounced only five death sentences during its period of operations, while WSS in Białystok pronounced only four of them). Such sentences were most frequently passed in cases that were evident and did not raise any doubts.

The situation became quite different, however, when the area was seized by the Red Army and after the formal disbandment of the Home Army, and that period requires further historical research. It cannot be ruled out that during the Soviet occupation and fratricide fights of 1944-46, the cases of such miscarriages of justice were frequent. Many controversies are raised especially by executions carried out under the so-called "selfdefence". Then, the role of a special court was limited only to approval or non-approval of execution that had already been carried out. Cases of the sentences approving such "liquidations" in the Rzeszów area have not been described yet. It has not been examined, either, whether the executed death penalties were necessary, or whether in certain cases it would have been sufficient to give the accused a chance of rehabilitation. It was a time of war, after all. Was it justified in such situation to require heroic and sometimes superheroic behaviour, and should persons incapable of such behaviour be sentenced to death

Operations (1994-1947), ZH WiN 2010, (Freedom and Independence Historical Studies) issue nos. 32-33, pp. 265-267. 
penalty? Decisions regarding the pronounced death penalties burdened the conscience of judges of the underground special courts.

\section{EXECUTION OF SENTENCES OF UNDERGROUND COURTS - CERTAIN CASES}

Actions involving the execution of death penalties continue to raise a host of emotions and controversies. All the more so, since the purpose behind the creation of the underground justice system was to countermeasure mob law, and even then that goal was defined as "difficult." As reported by Stanisław Broniewski, arguing against the use of scouts in sentence-related actions, an assault always carried a "fight" element, while execution of sentence usually involved "killing of a defenceless person." To protect alltoo-young soldiers of ZWZ/ AK, it was prohibited to employ under-age persons in the structures that carried out sentences. A liquidation action could have resulted in psychological devastation of young persons. How severe such trauma could have been is shown in the recently published memoirs of Stefan Dąmbski ${ }^{50}$. Therefore, special squads (the so-called hit squads) were appointed as execution bodies of WSS by relevant commands of ZWZ/ AK to be used to carry out execution sentences. As regards execution sentences, CSS hit squads were established by the Government Delegation for Poland. The best known execution squad was a Directorate for Subversion (Kedyw) squad codenamed "993/W" charged with the execution of death penalties mainly in the Warsaw area.

A similar execution "hit squad" in the area of Rzeszów District during the Soviet occupation was established by Mieczysław Kawalec "Żbik" (Wildcat), counterintelligence and subversion officer, and this "hit squad" was headed by Cadet Wiktor Tadeusz Błażewski "Orlik" (Spotted Eagle). Earlier the sentences were executed by "Mohort" special inspectorate subversion and sabotage squad (established in the autumn of 1944) and "Wedeta" squad set up to protect PUL (street propaganda) activities that jointly had as many as some 300 soldiers. An execution team that proceeded to carry out the approved sentence was usually composed of two crews: one of them was to prepare the action by way of observation of the convicted person, selection of the best place and time of execution and preparation of evacuation of the executors after task completion, while the second crew, usually composed of three persons (one shooter and two backers), was involved in the execution of the sentence, usually by shooting and reading to the convicted person the solemn formula saying "In the Name of the Republic of Poland..."51.

\section{SUMMARY}

Finally, it is worth noting that in the period from January 1941 to June 1944, Home Army soldiers carried out executions of the total of 5,733 officers of the German Police, Military Police, and the SS. Despite using the formula of the "death penalty sentence executed", those actions did not actually involve executions of sentences, but were only implementations of decisions of the Home Army command as part of common retaliation

\footnotetext{
${ }^{50}$ S. Dąmbski, Egzekutor (Executioner), Warszawa 2010.

${ }^{51}$ P. Ostaszewski, Podziemna Temida (Underground Scales of Justice). "Gazeta Policyjna” 2004 (Police Newspaper), issue no. 10, p. 11, B. Szyprowski, Podstawy... (The Basis of...), p. 10.
} 
campaigns staged by the Polish underground. Such campaigns against the occupiers did not require court sentences ${ }^{52}$.

Based on the estimated calculations made by historians, it seems that special courts in Kraków and Rzeszów pronounced about one hundred death sentences ${ }^{53}$. Dr P. Szopa has found 470 persons that were liquidated or attempts were made to liquidate them in the area of the Home Army's Rzeszów Sub-Region, which, by deducting one hundred persons sentenced by CSS, confirms that at least 350 cases were referred to a docket of WSS in the Home Army's Rzeszów Sub-Region ${ }^{54}$. T. Seweryn states that in the period from mid1943 to October 1944, CSS in Kraków pronounced 67 death penalties ${ }^{55}$. For comparison, as stated by Włodzimierz Lewgowd ("Bohdan"), a prosecutor of WSS in Białystok, the court passed only four death penalties in the two years of its operation ${ }^{56}$.

\section{BIBLIOGRAPHY}

[1] Borowiec J., Aparat bezpieczeństwa a wojskowy wymiar sprawiedliwości. Rzeszowszczyzna 1944-1954 (Security Police and the Military System of Justice in the Region of Rzeszów 1944-1954), Warszawa 2004,

[2] Dąmbski S., Egzekutor (Executioner), Warszawa 2010.

[3] Forystek J., Koryl Józef, “Piła” [in:] Małopolski Słownik Biograficzny Uczestników Działań Niepodległościowych (MSBUDN), (Małopolska Biographic Dictionary of Independence Movement Participants), vol. 17, Kraków 2015.

[4] Forystek J., Adwokaci w podziemnym wymiarze sprawiedliwości Podokręgu AK Rzeszów (Attorneys -at-law in the underground system of Justice in the Home Army’s Rzeszow Sub-Region), "Palestra" 2016, issue No. 13.

[5] Gondek 1., W imieniu Rzeczypospospolitej. Wymiar sprawiedliwości w Polsce $w$ czasie II wojny światowej (In the Name of the Republic of Poland. System of Justice in Poland during World War II), Warsaw 2011.

[6] Maruszak M., Działalność żołnierzy AK z plutonu dywersyjnego "Zagłoby" (19441952) w dokumentach UB (Operations of Home Army Soldiers from the "Zagłoba" Subversion Platoon (1944-1952) in the UB Communist Secret Police Documents), Zeszyty Historyczne WiN-u, (ZH WiN) (Freedom and Independence Historical Studies) 2005, issue no. 23.

[7] Maruszak M., Oddział Franciszka Rejmana "Bicza” i Leona Stowika "Uzdy”. Geneza, struktury i działalność (1944-1947) (Squad of Franciszek Rejman "Bicz" (Whip) and Leon Słowik "Uzda" (Headcollar). Origins, Structures and Operations (1994-1947), ZH WiN 2010, (Freedom and Independence Historical Studies) issue nos. 32-33.

\footnotetext{
${ }^{52}$ L. Gondek, op. cit., p. 162.

${ }^{53}$ W imieniu Polski Walczacej (In the Name of Fighting Poland) - interview..., p. 14.

${ }^{54}$ P. Szopa, op. cit., p. 239.

${ }_{55}^{5}$ T. Seweryn, op. cit., p. 214.

${ }^{56}$ IPN BU 1558/567, Armia Krajowa, Okręg Białystok (Home Army, Białystok Region), Report of the WSS prosecutor for 1942 and for 1943, sheets 7-8.
} 
[8] Ostasz G., Martynuska Władysław, [in:] Małopolski Słownik Biograficzny Uczestników Działań Niepodległościowych 1939-1956 (MSBUDN) (Małopolska Biographic Dictionary of Independence Movement Participants), vol. 4, Kraków 1999.

[9] Ostasz G., Okręg Rzeszowski Zrzeszenia „Wolność i Niezawisłość” (The Rzeszów District of the Freedom and Independence Association), Rzeszów 2006.

[10] Ostasz G., Podziemna Armia. Podokręg AK Rzeszów (Underground Army. The Home Army's Rzeszów Sub-Region), Rzeszów 2010.

[11] Ostasz G., Zagórski A., Akcja “Burza” w Inspektoracie AK Rzeszów (Operation Tempest in the Home Army's Rzeszów Inspectorate), Kraków 2003.

[12] Ostaszewski P., Podziemna Temida (Underground Scales of Justice). "Gazeta Policyjna" 2004 (Police Newspaper), issue no. 10.

[13] Seweryn T., Polskie sądownictwo podziemne (Polish Underground Courts), "Przegląd Lekarski" 1966, issue no. 1.

[14] Sieroszewski W., Przyczynek do historii Wojskowych Sąów Specjalnych (A Contribution to the History of Military Special Courts), Warsaw 1974, msp, Archiwum Wojskowego Instytutu Historycznego (Archives of the Institute of Military History), III/50/66.

[15] Sieroszewski W.,Organizacja wymiaru sprawiedliwości w Powstaniu Warszawskim $i$ udziat $w$ niej adwokatów (Organisation of the System of Justice in the Warsaw Uprising and Involvement of Attorneys-at-Law), "Palestra" 1977, issue no. 7.

[16] Szopa P., W imieniu Rzeczypospolitej. Wymiar sprawiedliwości Polskiego Państwa Podziemnego na terenie Podokregu AK Rzeszów (On behalf of the Republic of Poland. System of Justice of the Polish Underground State in the Territory of the Home Army's Rzeszów Sub-Region), Rzeszów 2014.

[17] W imieniu Polski Walczacej (In the Name of Fighting Poland), interview with Dr Bartłomiej Szyprowski, "Do rzeczy - Historia" 2014, issue no. 7.

[18] Wójcik Z.K., Kuś Andrzej, [in:] Małopolski Słownik Biograficzny Uczestników Działań Niepodległościowych 1939-1956 (MSBUDN) (Małopolska Biographic Dictionary of Independence Movement Participants 1939-1956 (MSBUDN)), Kraków 1997, vol. 2.

\section{PODZIEMNY WYMIAR SPRAWIEDLIWOŚCI W PODOKRĘGU AK RZESZÓW}

Podokręg AK Rzeszów, krypt. „Ogniwo”, „Woda”, obejmujący obszar zamknięty trzema rzekami - Sanem, Wisła i Wisłoka, a od południa granica słowacka został wyodrębniony z Okręgu AK Kraków dopiero w kwietniu 1943 r. Podokręg rzeszowski obejmował 4 Inspektoraty, a to: Rzeszów, Przemyśl, Jasło i Mielec, a w każdym z tych inspektoratów utworzono na bazach przedwojennych gmin po kilka Obwodów. W oparciu o zatwierdzone przez Naczelnego Wodza Statuty, powstały Wojskowe Sądy Specjalne (WSS) w ramach pionu wojskowego, a rok później w pionie cywilnym tzw. Cywilne Sądy Specjalne (CSS). Pierwsze wyroki dotyczące Rzeszowszczyzny zapadły już w $1941 \mathrm{r}$.

Wiele emocji i kontrowersji budzą akcje wykonywania wyroków śmierci. Jako organy wykonawcze WSS-ów powoływane były oddziały specjalne (tzw. bojówki) przeznaczone do ich wykonywania, a odnośnie wyroków CSS bojówki tworzone były przez Delegaturę Rządu na Kraj. 
Warto zwrócić uwagę, że w okresie od stycznia 1941 do czerwca 1944 żołnierze AK dokonali likwidacji łącznie 5733 funkcjonariuszy niemieckiej policji, żandarmerii i SS. Akcje takie jako wymierzone w okupanta nie wymagały wyroków sądowych. Z szacunkowych wyliczeń historyków wynika, że sądy specjalne w Krakowie i Rzeszowie wydały około 100 wyroków śmierci.

Słowa kluczowe: historia Polski, Polskie Państwo Podziemne, Armia Krajowa, Urząd Bezpieczeństwa, podziemie wojskowe, wymiar sprawiedliwości.

DOI:10.7862/rz.2016.hss.64

Przestano do redakcji: wrzesień $2016 r$.

Przyjęto do druku: grudzień 2016 r. 